
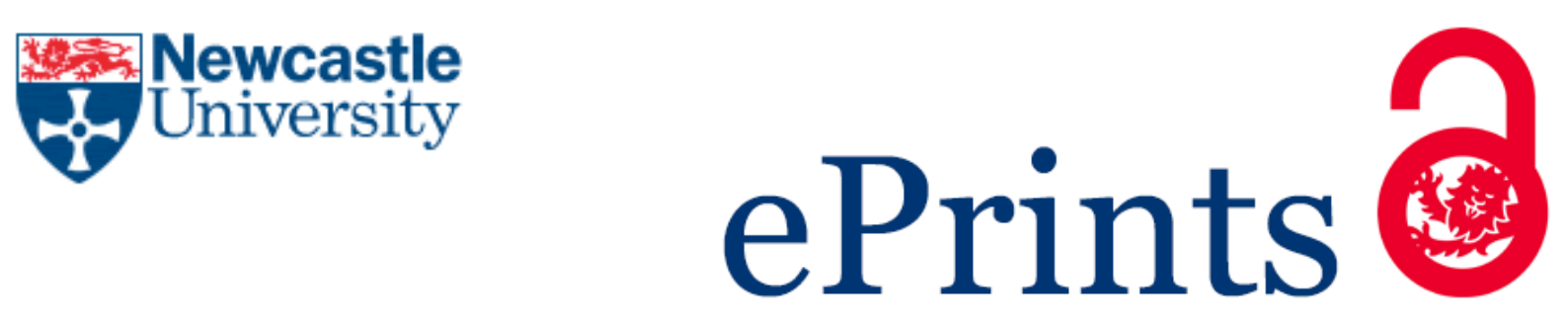

Mallett 0, Wapshott R.

Mediating ambiguity: Narrative identity and knowledge workers. Scandinavian Journal of Management 2012, 28(1), 16-26.

\title{
Copyright:
}

(C) 2012. This manuscript version is made available under the CC-BY-NC-ND 4.0 license

DOI link to article:

http://dx.doi.org/10.1016/j.scaman.2011.12.001

Date deposited:

$21 / 03 / 2016$

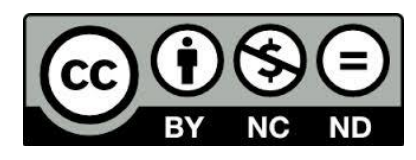

This work is licensed under a

Creative Commons Attribution-NonCommercial-NoDerivatives 4.0 International licence 


\section{Mediating ambiguity: Narrative identity and knowledge workers}

\section{Introduction}

The ambiguous context of knowledge-intensive work means that organisational changes, especially those that introduce elements of greater standardisation or additional job tasks outside of individuals' specialisms, potentially threaten knowledge workers' claims to highstatus, skill-full, creative work (Brante, 1988; Starbuck, 1992). These claims to specialism are an important element of knowledge workers' identities (Alvesson, 2001) and organisational changes that threaten them therefore provoke significant identity work. Using empirical material gathered from a longitudinal case study of a leading British graphic design firm, this paper explores the ways in which graphic designers (hereafter 'designers'), considered as knowledge workers, approach the identity work provoked by a significant organisational change.

The temporal identity work that these knowledge workers engage in to combat the vulnerabilities that may result from such periods of organisational change has yet to be fully explored. Derived from the thinking of Paul Ricoeur, we explore how narrative identity work mediates between multiple and contradictory personal and social identities in the workplace to mould plausible accounts of 'who I am'. Developing Ricoeur's conception of character and self-constancy in narrative identity work, we explore the types of process engaged in to mediate between these tensions. In addition to developing Ricoeur's thinking to understand identity work in an organisational context, we provide reflections for practitioners on the impact of organisational change for knowledge workers. 


\section{The ambiguities of knowledge work and knowledge workers}

'Knowledge-intensive work', while an ambiguous term in itself (Kelloway \& Barling, 2000), may be broadly understood as that which requires the application of intellectual capabilities directed towards novel or bespoke outcomes (Swart \& Kinnie, 2003a, 2003b). Given the specialist, non-standardised nature of this work, it can be problematic to substantiate the scope and depth of knowledge workers' competence, especially when they lack the established status, credentials and monopolies of traditional professions (Brante, 1988). Such work is therefore surrounded by ambiguities concerning the value of its outputs, the validity of its claims to specialism and the expertise of its workforce (Alvesson, 1993; 2001; Ibarra \& Barbulescu, 2010), with implications for individuals seeking to obtain recognition or a sense of legitimacy on which to base their claims to specialist status (Alvesson, 2001; see also Clarke, Knights, \& Jarvis, 2012).

In order to overcome the challenges of ambiguity, knowledge workers must invest significant effort to demarcate a niche area of practice (Alvesson, 1994), for example in persuading others of their specialist ability by commenting 'authoritatively' on matters arising within their claimed area of expertise (Swaminathan, 2001). Failure to do so places them outside of the community of specialists and can cause insecurities and other provocations to identity work (Collinson, 2003). Ambiguity-intensive firms undergoing significant organisational change might therefore anticipate conflict if claims to valued, specialist expertise come under threat. While previous research in this area has tended to take a managerial perspective (Covaleski, Dirsmith, Heian, \& Samuel, 1998; Gotsi, Andriopoulos, Lewis, \& Ingram, 2010), this paper will suggest a theoretical approach to understanding the temporal identity work provoked by organisational change as a key element of individual knowledge workers' lived experience (Hackley \& Kover, 2007). 


\section{Narrative identity work}

In response to tensions produced by organisational change, knowledge workers are provoked to engage in identity work. Identity work is the dialectic between a self-reflective, internal sense of identity and an outward facing external engagement and development of social identities (Watson, 2008; see also Sveningsson \& Alvesson, 2003). Social identity is supported by the creation and maintenance of ingroups, often in opposition to defined outgroups (Hogg \& Terry, 2000) and can, for example, be found in knowledge workers' niche areas of practice. Social identities can create pressures on individuals to conform and to align themselves in terms of an intersubjective interaction with fellow group members. Identity work seeks to manage the conflicts, contradictions and changes that arise from this personalsocial dialectic (Kreiner, Hollensbe, \& Sheep, 2006a, 2006b; see also Beech, 2008; Beech, McLeod, Cochrane, \& Greig, 2012). This paper is interested in the types of process through which identity work seeks to overcome these challenges.

Identity is inescapably temporal (Ricoeur, 1992); it is constantly in process, pulled back whilst pushing forwards, negotiating and adapting in the fluid, polyadic present (Dunne, 1996). Identity work is an ongoing process, interacting with internal and external motives, pressures, expectations and proscriptions (Ybema et al., 2009). Static pictures of individual identity are therefore that aspect of identity taken at a cross-section of an ongoing project of revision, negotiation, retreat and (re)invention. In contrast, a narrative approach provides a sense of continuity, linking past, present and future (Rasmussen, 1996). This paper will suggest that a narrative approach to knowledge workers' identity work provides valuable insights into individual lived experience in changing, ambiguity-intensive organisations. 
Narrative identity is a mode of self-experience (Eakin, 2006). Narrative evaluates action in terms of agency and, in doing so, gives action meaning (Dunne, 1996). Through emplotment, it mediates between individual actions and heterogeneous events within a temporal context (Boje, 2001). We therefore distinguish between narrative processes of emplotment and stories as the artefacts of these processes. It is in this creation of stories that we recognise our selves, but this act of recognition is not limited to the stories we author, we also recognise our selves within the stories of others. It is within this potentially mutual recognition that the other stands, introducing an intersubjective sense of 'belonging', or of social identity (D. Brown, 1997). It is in this ongoing, dialectical process of self-interpretation that narrative becomes a 'hermeneutics of testimony', attesting to the intent that informs experience, as an otheroriented report and not an original perception (Ricoeur, 1980).

The 'narrative turn' in organisation studies (Alvesson \& Kärreman, 2000; Cunliffe, Luhman, \& Boje, 2004; Czarniawska, 1997; Rhodes \& Brown, 2005) has provided researchers with a means engaging with the temporal without losing sight of relational or cultural factors (Somers, 1994). However, narrative approaches to identity have been criticised under the banner of 'narrative imperialism' (Phelan, 2005; see also, Strawson, 2004; cf. Eakin, 2006). The suggestion is that narrative theorists have expanded beyond their means, that they attempt to explain phenomena within too restrictive a set of concepts, simplifying complex processes. Despite such criticisms, narrative approaches have provided a refined understanding of the complexity and causality involved in processes of change (Tsoukas \& Hatch, 2001) and identity (Hytti, 2005; Slay \& Smith, 2011), emphasising the need to retain the complexity and messiness of working lives. These approaches embrace fluidity and multiplicity (Ezzy, 1998; Rhodes \& Brown, 2005) and the range of individual voices and experiences within organisations (Brown, 1998). They therefore resist the temptation to edit events in search of a 
cohesive or compact story of people's lived experience (Steyaert, 2007). The value of narrative approaches to understanding temporality and complexity in identity work suggests their relevance to the present study.

\section{A Ricoeurian approach to narrative identity work}

In order to explore the narrative identity work processes that seek to engage both the temporal and potentially multiple or contradictory tensions, this paper adopts a specifically 'Ricoeurian' approach to narrative identity. Ricoeur $(1988,1991)$ successfully builds on and develops earlier approaches to narrative (Boje, 2001) and to multifaceted identity (Ezzy, 1998), providing a theoretical 'middle way between the humanist and poststructuralist self' (Reedy, 2009, p.115). As Ezzy (1998) outlines, whereas Mead (1934) conceived of memories and anticipations perceived as objects organised by the individual to provide meaning, Ricoeur suggests a hermeneutic self-interpretation that links narrative process and lived experience, providing a sense of stability in the face of conflict, complexity and uncertainty.

Ricoeur conceives of identity in terms of a distinction between idem (same) and ipse (self) identities (1992, p.117-8), the simplification of which obscures attempts to understand identity (Ricoeur, 1991, p.73). On the one hand I remain the same person throughout my life, there is only one protagonist of my autobiography. In this respect, there is a sense of sameness and unity to experience, memory and expectation (idem identity). However, who I am changes as time progresses and, whilst there is a unity, the ways in which I act, perceive and interpret may alter from moment to moment (ipse identity). In everyday life, how I act, what characteristics I exhibit, may vary a great deal, but there is a 'permanence-in-time' which means that I remain the same individual. Ricoeur suggests that narrative self-interpretation provides a mediating function between two 'poles' of identity. One pole is that where the idem and ipse overlap, the other is where a gap opens up between them. 
Ricoeur (1992, p.121) uses the terms 'character' to refer to the first pole, a temporal permanence when the idem and ipse overlap, that is we when act in a consistent way, 'in character'. This sense of consistency ensures that changes in self-interpretation occur only very gradually, in terms of two 'notions of disposition': habit and identification. Character traits, habits, are acquired through experience and, by repetition, given a sense of stability (Rasmussen, 1996). Opportunities for formative identifications arise in terms of the 'values, norms, ideals, models and heroes, in which the person ... recognizes itself' (Ricoeur, 1992, p.121, original emphasis). In this way we recognise ourselves in the stories of others, we appropriate their stories for our self, and can come to form particularly strong, sedimented attachments to particular social identities.

The second pole, where idem and ipse are far apart, where the individual is acting 'out of character', Ricoeur (1992) conceives of the 'self-constancy' involved in keeping one's word. This is a form of faithfulness in identity and action that can lead to innovative change in a sense of one's identity. It is in engaging with the dialectic tension between idem and ipse identities, requiring mediation between character and self-constancy, that a narrative identity approach embraces change and multiplicity, moving away from a unified life story approach that cannot be sustained amid the pressures of internal self-reflection and potentially competing and contradictory external engagements and influences. Given its intersubjective appeals to accountability (Dunne, 1996), a Ricoeurian conception of narrative identity work is therefore a potentially useful concept in understanding responses to some of the identity pressures encountered in the work place (see, for example, Sparrowe, 2005; Ibarra \& Barbulescu, 2010; Durand \& Calori, 2006).

Ricoeur's conception of narrative identity has encouraged regular citation as a potentially helpful aid to understanding identity in organisational contexts (Brown, 2001; Coupland, 
2007). However, while these writers have noted the potential of a Ricoeurian approach, his ideas have yet to be fully utilised and 'narrative identity' as a concept has received limited critical attention to-date in organisation studies (Jabri, 2004, 2009; Hamilton, 2006). This paper seeks to further suggest the value of these ideas and explore the narrative processes involved in knowledge workers' identity work and its mediation of the tensions provoked by organisational change in ambiguity-intensive contexts.

\section{Methodology}

A research interest in knowledge workers' identity work emerged from an 18 month, in-depth exploration of a graphic design company during a period of organisational change. UKDesign is a successful and prolific producer of industry award-winning creative design work for business-to-business and business-to-consumer clients. The designers employed by UKDesign, like many other knowledge workers, are well-educated specialists applying their technical skills and creative abilities to produce bespoke solutions to complex client problems.

Design is a type of knowledge business (Lei, Slocum, \& Pitts, 1999; Swart, 2007) and the industry body, the Design Business Association (DBA), lays claim to design as a specialist business service through its provision of 'professional practice' training programmes and its stated objectives, reinforced by annual 'Design Effectiveness Awards' (DBA, 2011). However, as with other knowledge workers, while designers' specialist skills are required inputs to client services, it is only in so far as these talents can be translated into clientpleasing outputs, through an understanding of the clients, their markets and customer base, that they become commercially valuable (Michlewski, 2008). The ambiguity-intensive pressures experienced by knowledge workers were common to UKDesign, where, during the 
present study, designers who greatly valued their expertise were exposed to an organisational change that was perceived to move away from the previously central creative aims.

UKDesign was originally approached as part of a larger study into professional service and knowledge-intensive firms' management practices. This element of the study was diverted when initial interviews discussing working life at UKDesign revealed interesting individual stories (Gabriel, 2000) about the organisation and individuals' identity work. These stories were explicitly related to changes in the organisation towards more constrained corporate work that threatened the specialist enclave that had previously helped reinforce the designers' identity claims. Capturing insights from such a changing organisation therefore provides a valuable opportunity for the study of identity work in progress, avoiding the dangers of retrospective, (re)constructed accounts (Deuten \& Rip, 2000).

\section{Field work}

The qualitative empirical material (Alvesson \& Kärreman, 2011) was gathered from company documents, observations and semi-structured interviews. Over 100 hours of observations were carried out within the firm, including attendance at creative meetings and various informal gatherings. Observations provided valuable opportunities to understand relationships within the organisation, for example watching an experienced designer's muted response as a non-specialist senior business manager provided some 'guidance' (in reality, direct instruction) on the subtleties of her design work. While not discussed in great depth in the paper, such observations proved a valuable context for understanding and interpreting the interview material and helped build rapport between the researcher and participants (Alvesson, 2011). On-site presence also allowed access to internal documents such as newsletters, management policies and business strategy documents in addition to materials 
for public consumption such as company values statements which featured prominently in pitches to prospective clients.

Thirty-four semi-structured interviews, each typically lasting an hour, were conducted with staff across the organisation. The interviews were focused on understanding working life at UKDesign and often provided a platform for broader discussions. Questions around how staff had come to join the firm, for example, often led into discussions of how the company had changed. All formal interviews were recorded and transcribed, the one exception being a selfconsciously dynamic manager who preferred to talk over an informal pub lunch. The principal participants featured in the analyses below were each formally interviewed twice during the research, in addition to informal interactions during observations.

\section{Analysis}

Initial analysis, conducted as part of the early research phase, was aimed at reducing the empirical material into manageable categories (Miles \& Huberman, 1994). In exploring the interviews we were drawn to the significant identity work provoked by organisational changes and, as the focus for the research altered, the analysis moved away from coding for reduction and instead centred on the designers' stories of their careers and experiences at UKDesign. Gathering together designers' interview transcripts we studied their personal accounts of their careers and experiences at UKDesign. Reading these accounts, we focused our attention on instances of temporal identity work. We were particularly interested in those stories where designers explained tensions between their sense of being a specialist designer and the types of non-specialist work increasingly required of them. Focussing in particular on how the individuals described those challenges and tensions they had faced during the organisational change, we sought out forms of emplotment (Boje, 2001). Through our close 
readings of designers' accounts we were able to appreciate the identity work undertaken and the types of narrative process deployed to mediate the tensions and contradictions.

Given the emergent nature of the themes identified in the designers' stories, no formal testing was completed for agreement between the authors. Instead, disagreements were resolved through discussion and recourse to the empirical material. Reading these stories as forms of testimony (Ricoeur, 1980), we were sensitive to the intertextual nature of emplotment (Boje, 2001), whilst attending to the stories produced as narrative constructions in their own right (Cunliffe, Luhman, \& Boje, 2004). The stories were analysed with reference to literature on identity work and the ambiguities of knowledge work in more general terms. This required frequent moves back and forth between the literature and the analysis itself as we explored the concepts developed as a platform for theoretical development (Alvesson, 2011; Alvesson \& Kärreman, 2011; Elsbach, 2003).

The presentation of our findings and analysis focuses on three individual UKDesign employees, using these cases to explore different reactions to the organisational changes in which identity work was particularly pronounced. The issues encountered and responses discussed differ but, when taken together, are broadly representative of the types of issues encountered with other participants. In collecting, analysing and presenting participants' stories, we recognise them as delicate and prone to distortion or misrepresentation (Sims, 2003). We therefore concentrate attention on a limited number of participants in order to allow space for their stories to be presented in greater depth than might be achieved through presenting many brief and fragmented accounts that risk dissociating perceived 'facts' from their narrative context (Czarniawska, 1997). 


\section{Findings}

Our findings focus on the stories in which participants discussed the nature of the tensions created by the organisation's changes. To convey something of the context and progression of the stories that arose from these changes, we present our findings around three individual designers' accounts: Lisa, a relatively new recruit involved in UKDesign's semi-independent 'Client Team'; Ian, a recently promoted 'senior designer' adapting to the changing organisation and his role within it; and finally Nathan, a 'senior designer' in conflict with aspects of the organisation as a result of these changes. However, we first provide the organisational context and describing the changes in which UKDesign was engaged.

\section{UKDesign}

UKDesign is a leading player in the design industry. Based in England, though outside of London, the business has existed independently for around 18 years, owned by its founder and board members. Beyond the board team, which is responsible for UKDesign's strategic planning, creative direction and financial security, the organisation operates with a relatively flat structure. While the newly created 'senior designers' have some responsibility for mentoring staff and undertaking business administration tasks, the role remains ambiguous in its relationship to company management and the specialist design aspects of the firm. Other designers are only distinguished informally as 'middle-weight' or 'junior' by virtue of their design experience. Alongside the designers, UKDesign has an administrative structure for marketing, human resources, IT and project management that has developed as the company has grown.

Laying claim to their work as involving technical expertise and creativity was common to all the designers interviewed. This expression of creativity represented the preferred application 
of their technical skills and generally exceeded any importance attached to meeting clients' requirements. This is in contradistinction to the aims of the organisation since, while creativity is an important element in the deployment of designers' specialist skills in the production of bespoke outcomes, what is key in defining their is the requirement for it to meet the needs of clients. The commercial viability of what the designers perceive as creative, specialist work therefore produces a paradox inherent in their identities at work (Gotsi, Andriopoulos, Lewis, \& Ingram, 2010).

This tension between commercial necessity and the preferred creative expression of a broad range of technical, specialist skills, was heightened as UKDesign entered a period of significant organisational change. The primary driver in the changes underway at the commencement of the study was a move to higher-paying, large corporate clients with less need for innovation, wide-ranging technical skills or creativity. Stimulating projects requiring expertise to revive a client's business through fresh branding, design and market positioning were being squeezed out by work producing standard corporate branding or unglamorous business-to-business promotional literature. This work threatened the specialist enclave that had previously helped reinforce the designers' identity claims as valued knowledge workers.

\section{Lisa: the Client Team}

At UKDesign, work was traditionally organised around particular projects so that designers' time was divided between a series of tasks for a variety of clients. However, as the organisation changed, an exception to this varied way of working emerged in what was designated the Client Team. ${ }^{1}$ Within this team, designers are allocated to a particular client and will spend much of their time producing design work for them. These clients have strict 
guidelines regarding branding and this kind of 'mass application' or re-production of codified knowledge rarely requires expertise to be applied in the resolution of novel, complex problems. It is therefore on the fringes of what may be considered knowledge-work (Swart, 2007).

This was the experience reported by Lisa, a junior designer who had recently joined UKDesign for its industry reputation and a client list that would enhance her fledging résumé. She was very focussed on the importance of building a career on a strong foundation in the industry so, despite her original plan to live in London, UKDesign's reputation made it too good an opportunity to decline.

Lisa described work in the Client Team in terms of 'creative constraints' making it particularly challenging, especially in transition from the freedoms of her university training and in contrast both to her expectations and the types of work that had previously been available to junior designers at UKDesign. Lisa explained:

Even though, they, like at the moment we're having a bit of a quiet patch with [Client One]. [...] which has been really good so I think I've momentarily forgotten (INT: Right, ok) that, or that I hate [Client One] or whatever (laugh) [...] it's something that I'm aware that I don't want to get...stuck in. Because I think it would be hard to get out of it (INT: Sure, once you've) once you're pigeon-holed into it, and also from a young, as a junior I think it's really important for me to be challenged and stretched and and do stuff that I can't do (INT: Right, ok). [...] eventually I want to work my way up and be a, a good graphic designer in different things, not just packaging.

It is through the conventionalisation brought about through training at university and work placements that many of what Ricoeur (1992) refers to as stubbornly prolonged dispositions 
(habits and identifications) are acquired in relation to designers' identities. We suggest that character traits, habits, are acquired in the early instances in which a particular type of specialist work is conducted and reinforced (and conventionalised), sedimented over time. In this way, "habit gives a history to character" (Ricoeur, 1992: 121). For junior designers such as Lisa, her habits related to the application of a broad range of technical skills and forms of creativity, giving a history to her character and informing a sense of her identity. At the same time, this sense of character is supported by those formative identifications that present themselves throughout the training process. It is through identification that the expectations of the 'designer' role are therefore developed and through which the sense of a social identity is formed.

Lisa was very focussed on her career and what she wanted to achieve. She initially viewed the less creative Client One work not only in the context of other, more pleasing types of work such as the work she engaged with as a matter of habit at university, but also as a stage in her career, one that she must progress from as soon as possible in order to develop, to be 'challenged and stretched'. This story of 'career development' allowed her to reconcile her sense of character, developed through habits and identifications at university, with the contradictory realities of constrained work in the Client Team. To shore up this story of career development, to maintain a sense of herself as a designer in the face of unchallenging work tasks, Lisa created stories that associated her self with a particular social identity and with the stories told by and about other members of the occupational niche or 'ingroup' (with corporates as an 'outgroup'; see also Ybema, Vroemisse, \& Van Marrewijk, 2012).

I think we all, I think it's true to say that we, I feel the difference between the creatives and the corporate in the, in the company. 'Cause I think that when I sit with the designers, we're a lot more loose and sort of, you know. 'Cause we're creative we like 
to read magazines and stuff (laughs) (INT: Yeah) And then a you've got the ... corporate people who do, a lot of them sit upstairs actually

[...] we are like two different types of people even though I don't think they'd like me to say that (INT: No) Because everyone's supposed to be UKDesign...type people...

However, this storied explanation for her position in the Client Team was not sustainable. The tension between Lisa's sought-for identity as a respected designer and her role within UKDesign was placed under greater pressure as she later described how, among designers at the firm, Client One work had been stigmatised as 'corporate and uncreative'. It is perhaps unsurprising that Lisa soon left UKDesign to join a firm where she anticipated gaining experience of new design challenges and benefiting from more intensive coaching to foster her development.

\section{Ian: adapting to the changes}

During the organisational change and growth in employee numbers, UKDesign encouraged the careers of existing employees, for example through the appointment of 'senior designers'. One such appointee, Ian, had been with UKDesign for around eleven of his fifteen years in the design industry, joining from a smaller company where training and development was informal and he had taught himself various technical skills. He had seen how UKDesign had changed as it had grown, acquiring greater levels of formality in operating procedures as it changed focus to winning work for major brands. Ian expressed some discomfort at the increasingly commercial focus of the business:

Much more commercial. (INT: Commercial, and) yeah, the results and the, the bottom line matter, very much at the moment, more than our creative output (INT: Right)

Which does influence obviously, how long we get to spend on jobs (INT: Yep) and 
the resource we use, and everything [...]. I think they need to get the balance back a bit more.

As part of his new role, Ian had to take on more managerial responsibility, greater client interaction and mentoring less experienced colleagues. This meant he was required to drive elements of the organisational change. However, it was clear in the stories he told that Ian continued to seek the creative element in this relatively constrained work:

My role now, really erm, after working on a great deal of business to business communications, is to work on quite complicated, erm, strategies and, and er communications that are required for erm, major organisations like [names clients], and organisations like that and try and create a very clear and distilled message for erm, things that can be quite complicated... in a very creative way (INT: Good, ok) As well as still being turned-on by all the sexy projects that are much more artistic (INT: Do you) as a designer.

Ian appeared comfortable adapting to the changing environment, albeit with some reservations. He described the changes in terms of his own development:

One of the skills I've really heavily picked up is to really talk the client's language to a certain degree as and how the design and solutions I'm doing are going to: one, answer their brief, go beyond that brief but ultimately affect their bottom line and that's what I'm here for, to do. I'm not here to do pretty pictures but if we can make both work ultimately then we will do.

The client-facing work had taken on a greater emphasis in Ian's career and, despite its distance from the use of technical, specialist knowledge, it was part of 'what I'm here for, to do'. He described how he had begun to realign his commitment to high standards of design 
work towards client satisfaction and away from design as an end in itself. In an interview shortly after his promotion, Ian explained:

I mean some people want to progress, others don't and others stay hands-on. Ultimately there's...they can run a business and still be a designer, there's many examples of that from [names some design firms] and organisations like that that have designers at their helm so it does work.

Unlike work in the Client Team, which Ian had deliberately avoided, this less design-focussed work had more status attached to it and echoed thoughts he had previously expressed around how he had always pushed himself to develop. Further, Ian could easily tie the new work tasks directly into the results that are produced by the exercise of more traditionally recognisable forms of knowledge work. Further, in coming to terms with his new position, Ian refers outwards to a newly identified occupational niche: successful designers at other organisations who also have managerial responsibilities. In doing so, he has made new identifications that, over time, may gradually become sedimented and come to be viewed as part of his character. In this way, a narrative process drags the ipse and idem identities closer together. This change in identification is potentially significant enough to act as a 'paradigm shift' (Ricoeur, 1984: 69), an innovative experimentation in narrative identity that shakes free some of the previously sedimented dispositions.

As a senior designer, Ian has had to be more 'hands-off' in order to fulfil his responsibilities to UKDesign's clients and he spoke enthusiastically about enjoying high levels of involvement and control. However, minutes later he argued that the top designers should have fewer distractions, which reduce the quality of creative output and efficiency. This suggests a tension and, possibly, a period of transition. In making this transition, Ian takes implicit 
support for this potential shift in identity from stories about his newly identified role models, allowing him to defer some of the specialist activity, the material production of the design work itself, to those staff he now manages:

I've had to be much more hands-off in terms of doing the job. Doing the job is my passion and I find that incredibly difficult as most designers I've been told who go through this transition do, and it's trying to find ways to keep the team motivated and to deliver the quality of work required to put ourselves on the map and to ensure that we gain a reputation to do, to doing some of the best work in the world. And that's still the target and aim but it won't be done probably through personal hands-on, I'm having to develop new ways of working with a team that are very junior...

The support derived from stories about his newly-identified role models is very clear: any difficulties are the common experience of designers like him. Ian can, in this way, identify himself in the stories of others and over time he came to embrace the organisational changes. However, not everyone at UKDesign found the business' trajectory to their liking.

\section{Nathan: conflict with the changing organisation}

Nathan is a senior designer who joined the company around the same time as Ian. In describing his role, Nathan explained that 'senior designer' 'is a bit of a loose, woolly term for somebody who's been here a long time!' His original application to join UKDesign had been speculative and he attributed his career progress to luck. Like Ian, Nathan had watched the company change, describing a very negative picture of its development. He perceived the increasing commercialisation of UKDesign as a self-perpetuating nightmare where '[a]s the [UKDesign] monster gets bigger, it requires more feeding'. He felt that, by shifting focus away from creative output to become more 'hard-nosed', UKDesign had become a less 
enjoyable place to work. Although the clients remained satisfied, Nathan said that the designers felt their output required less specialist expertise. Nathan voiced his objections in terms of integrity:

...we wouldn't be who we are then because that's not what we're about. [...] Lots of other people do that [large-scale corporate work], that's fine but it's not what a design company's about.

Although the knowledge workers at UKDesign recognised that the shift from expertise as a creatively-led organisation to a more corporate business environment had been taking place over several years, the introduction of more explicitly 'corporate' structures, such as the use of a 'balanced scorecard', provided a focus for the tensions. The scorecard measured teams within the business against targets in Financial, Creative Awards, Press Coverage and Teamwork categories. This prompted concerns about the organisation's approach to performance assessment. As Nathan explained:

the last thing I've got on my mind is PR points, my job's a designer...It's somebody else's job to sort out the fucking PR for this company, not me.

Nathan repeatedly and clearly distanced himself from the changes in the organisation. So, even though his role required him to follow revised practices such as the performance appraisal scheme, he continued to create stories that distanced him from the actions he viewed as 'not what a design company's about'. Nathan:

I could have got this completely wrong...I think this ties in to our, whatever it's called...(long pause)...anyway this thing, the structure we've got in place (INT: The balanced business scorecard?) That's, that's the one...To be honest with you I'm not a 
great advocate for this, I'm probably not the person to speak to! I don't really understand that either!

In this example, representative of designers' understanding of the firm's performance measurement system, Nathan implies that he does not understand important parts of the business infrastructure. The balanced scorecard is attributed to managers and significantly distanced from the specialist, non-business realm of the designers. Whilst the performance measurement system aims to categorise and measure the outputs of knowledge workers, it is perceived as threatening the specialist status necessary to maintain a valued conception of designer identity. Any internal tension in Nathan's sense of self as he engages with the new appraisal system is avoided by holding the ipse close to the stability of the idem. Any discordance is written out of the narrative as an act of insincere compliance. It is not 'real'.

\section{Discussion}

Our findings suggest some of the ways in which, during a period of organisational change, designers were exposed to tensions familiar to many knowledge-workers. Engaging in identity work, the designers frequently created stories which considered their sense of personal identity in relation to social identities, most prominently that of being a designer. While addressing challenges to their identity claims, they regularly referred outwards, interpreting their sense of self whilst searching for support and recognition in the stories of others. Further, this identity work was temporal, referring back to a remembered past but also forwards to anticipated futures and to other previously anticipated futures. Developing a narrative approach, we will now discuss how identity work seeks to mediate tensions and negotiate the constraints and requirements of changing, knowledge-intensive organisations. 
Analysing the processes of identity work through a Ricoeurian lens facilitates the exploration of the ways in which knowledge workers configure and maintain their potentially vulnerable, multi-faceted identities through the theoretical distinction between idem (same) and ipse (self) identities. The two poles of identity, where idem and ipse overlap (character) and where they are apart (self-constancy), allow us to conceive of a dialectic at the heart of identity work. In the tension between these two poles of identity, where the multiplicity inherent in identity is pushed too far, narrative is required to mediate (Ricoeur, 1992). It is within this theoretical framework that we will discuss the narrative processes deployed by the designers to cope with the challenges and tensions presented by the organisational change.

At university and in other forms of training, the designers in our study had developed an identification, internalisation and accumulation of habitual behaviours. The conception of one's character, and the career stories such characters will inhabit, is the result of an intersubjective process of individual perception and internalisation through which the expectations of the 'designer' role are established. The formation and sedimentation of the related habits and identifications develops a sense of an ingroup of which one desires to be a member and begins to identify with to the extent that this social identity is an important anchor for one's sense of self.

A discordance between who one wants (or expects) to be and what one is doing can be mediated by various narrative strategies. However, there can come a point at which this concordant narrative frame no longer holds. If we cannot recognise our selves in the actions carried out as part of a job role, nor within the stories of our colleagues, our sense of character begins to lack plausibility and claims to a particular identity become threatened. For example, junior designer Lisa projects a narrative of her future that is derived from her identifications and the ambitions these fostered, the prototypical career story (or 'projects', Grey, 1994; see 
also Hallier \& Summers, 2011) against which she is measuring her progress and forming value judgements about her current job role.

Initially at least, Lisa could reconcile the less specialist work she was doing through its place in her broader career development as a designer: this work is only temporary and will lead to greater challenges and rewards. In this way 'career development' stories can cover a multitude of sins or, more precisely, bring narrative concordance to a multitude of discordant acts. However, the mediating narrative process that kept the encroaching doubts at bay became unsustainable and implausible without support from the organisation (for example by varying work tasks, Gotsi, Andriopoulos, Lewis, \& Ingram, 2010). This story collapsed at the point Lisa felt her role in the Client Team was holding her back, negating any sense of career development and explanation of her place as part of the team, excluded from UKDesign's niche area of specialist practice. Struggling to confirm a place within this ingroup, Lisa's story explaining to her self her less specialist and less valued role, why she was acting 'out of character', began to lack support and plausibility. Ambiguities unmanaged, Lisa began to find her role at UKDesign untenable.

A knowledge worker may be acting out of character by subordinating their specialist skills or creativity to formulaic or non-specialist demands. However, narrative can mediate this conflict through a sense of keeping one's word, for example to the organisation or to the client to whom they are accountable. Such behaviour, a form of self-constancy, is identified as being within their sense of who they are. Further, there is also the opportunity for innovative identity work in which identification is made with a new ingroup, new habits formed and, gradually, a modified sense of one's character begins to emerge (Rasmussen, 1996). Ian recognised himself in the stories of a respected professional niche, successful designers at other organisations who have managerial responsibilities, in a reconfigured anticipation of his 
future career. This shift in his social identity to a new (desirable) ingroup supported and reinforced the value ascribed to his current job role, helping to minimise the potentially negative results of the tensions surrounding his changing role. In configuring his new position, Ian's sense of his self gradually developed, enabling him to engage productively with the organisational changes.

The potential for narrative identity work to mediate contradiction can be seen in the present study where designers adopted an alternative narrative process, allowing themselves to be 'mystified' (Goffman, 1959, p.58) by certain aspects of the business. Whereas Ian's habitual behaviour and identifications altered and his conception of himself followed, a contrary approach can be adopted where a failure or refusal to understand the change is heightened to disengage from and alienate the new skills or behaviours. Where the actions required by the organisation cannot be related to the familiar habitual actions associated with one's character they are rejected as incompatible with the position and status of a knowledge worker. This was demonstrated by Nathan's attitude towards the balanced scorecard. The apparent rejection of these measures can be read as a designer making a claim to a knowledgeintensive, specialist identity, and a denial of those conventionalised characteristics associated with what was termed 'effective design' and was viewed by many as formulaic, routine forms of work.

The stories Nathan tells, that appear to reflect his ongoing negative characterisation of his relationship to the organisational change, continue the distancing process and suggest that he views himself as acting out an insincere role when he does comply. There is a reaction detectable in Nathan's response to what he perceives as the increasing commercialisation of UKDesign that suggests he views those characteristics in opposition to his understanding of himself as a designer. This suggests a form of 'dis-identification' (Elsbach \& Bhattacharya, 
2001; see also Beech, McLeod, Cochrane, \& Greig, 2012) in which Nathan is distancing himself from a perceived management outgroup. The aspects of the change that risk damaging claims to specialist expertise are 'written out' out of the story as an act of insincere compliance. Any actions that conform, and are therefore at odds with the story but not written out, can still be accounted for through processes such as mystification or external compulsion in the infinite narrative malleability of the past (Fleming \& Rudman, 1993; Strangleman, 1999).

Narrative identity work processes mediate the dialectical tensions between the idem and ipse identities, embedding contradictions and multiplicity within viable plots that embrace the remembered past (even while subtly amending it), experienced present (while interpreting it) and (perhaps newly) anticipated future. It is in this way that our Ricoeurian approach to narrative mediation helps counter some of the criticisms of narrative identity approaches that suggest they produce unitary, well-integrated conceptions of the individual (Alvesson, 2010). The strength of our approach lies precisely in its conception of identity as multiple, conflictual and polyphonic (Belova, 2010). It is to a sense of character that individuals feel a tie of fidelity but that shifts within hermeneutically reinterpreted self-narratives. Character is relatively stable and will only shift over time through paradigmatic reorientations such as those described by Ian who was able to identify with and draw upon their stories of respected others, his narrative self-interpretations re-engaged and revised. However, there is scope, at least in the short term, to sustain contradiction and discordance through narrative processes that relate, for example, to career development stories or forms of mystification, such as with Lisa and Nathan respectively.

Our Ricoeurian approach to narrative identity work allows an appreciation of the conflicts and mediation between personal and social identities within a context of temporality and 
contradiction. This approach is particularly relevant to the complexities involved in the identity claims and threats experienced by knowledge workers in periods of significant organisational change. It reveals important insights into knowledge workers' experiences of these changes and the ways in which they attempt to mediate between competing demands in search of a stable personal identity in the workplace. While narrative solutions to tensions can be improvised or drawn upon externally these are unlikely to be sustainable in the longer term unless new habits and, potentially, new identifications are developed. Whether such changes in individual knowledge workers' characters and therefore in their sense of who they are is warranted or desirable is for those individuals to decide. If discordance between the identity work of an individual and the goals and direction of the organisation, and therefore the work tasks and social identity of the individual, cannot be mediated in the long term then this paper has suggested the result may involve psychological discomfort, non-compliance, poor performance or valuable knowledge workers leaving the organisation.

\section{Conclusion}

Claiming a particular identity (such as being a specialist or knowledge worker) 'exerts a moral demand upon the others, obliging them to value and treat him [sic] in the manner that persons of his kind have a right to expect' (Goffman, 1959, p.11). These obligations create tensions both within the individual whose identity claims are threatened but also in the broader workplace, involving relations that may be particularly important to organisations reliant on valuable knowledge workers. A narrative perspective provides insights into the identity work of individual knowledge workers and the implications for the introduction of significant organisational change. 
Designers at UKDesign represent an interesting case because the increasing commercialisation and formalisation of the business and the resultant changes in their job roles threaten the specialist enclave that has supported their claims to value and status. Developing a Ricoeurian narrative approach to identity work, we have described the processes through which these workers maintain, revise and mediate their sense of personal and social identities. Three clear narrative strategies emerged in this paper (though not necessarily consciously on the part of the individuals): identifying with and drawing on the stories of respected others; developing stories of career development; and justifying noncompliance through stories of mystification. We do not suggest that this list is exhaustive but, rather, that it represents some of the characteristics of narrative processes drawn upon in the identity work of these designers. Our analysis therefore contributes to understanding the lived experience of designers specifically and of knowledge workers more generally because the ambiguity-intensive environment at UKDesign and the pressures placed upon the designers' claims to valued specialism during increased formalisation are common to many knowledgeintensive firms (Alvesson, 2001).

By drawing on Ricoeur's conception of narrative mediation between the two poles of character and self-constancy, this paper has proposed a subtle approach to appreciating the dynamic, dialectical tensions involved in identity work and the search for stability in individuals' sense of who they are. In doing so this paper has responded to those who have called for Ricoeur's work to be further developed in organisation studies (Brown, 2001; Coupland, 2007). The approach we have developed encompasses the tensions between the personal identity of the individual and the social identities derived from, for example, their occupational niche. It is also sensitive to the potential for contradiction and the importance of 
a temporal understanding of identity, narrative processes providing a bridge between the remembered past, experienced present and anticipated future.

Reflecting on our findings, practitioners might pause to consider how organisational changes impact on knowledge workers. The significance of certain types of task to knowledge workers might be more far-reaching than is appreciable from outside that specialism, and be perceived as challenges to the identity claims of these workers, creating vulnerability amongst the employees and dispute within the organisation. Where the demands on staff provoke them to refigure their sense of personal identity it is important for organisations to provide space and narrative resources to support individuals' identity work. This can be clearly seen with Lisa who lacked opportunities to support her story of career development which may otherwise have been able to justify the time spent on non-specialist tasks. The potential for this approach is also seen with Ian who was able to recognise himself in the stories of a potential new ingroup with which he could then identify and begin to develop his sense of identity. The dangers of failing to support knowledge workers' narrative identity work can be seen in the case of Nathan who fakes compliance. Managers must also recognise that individuals at different career stages may be more or less well-equipped to deal with the challenges they face. However, the deeply personal nature of identity work makes it hard to generalise too widely about those at similar career stages, as the contrast between Ian and Nathan indicates.

Further research might explore how far the approach developed here holds explanatory power in other contexts, for example in other types of occupations operating in ambiguity-intensive environments and facing challenges to workers' sense of personal and social identity. This paper has also suggested the value to management and organisation studies of the narrative identity approach of Paul Ricoeur. There remains great scope for these ideas to be further 
developed and to illuminate many areas of organisational life where individuals' identities cannot be ignored. 


\section{References}

Alvesson, M. (1993). Organizations as rhetoric: knowledge-intensive firms and the struggle with ambiguity. Journal of Management Studies, 30 (6), 997-1015.

Alvesson, M. (1994). Talking in organizations: managing identity and impressions in an advertising agency. Organization Studies, 15 (4), 535-563.

Alvesson, M. (2000). Social identity and the problem of loyalty in knowledge-intensive companies. Journal of Management Studies, 37 (8), 1101-1123.

Alvesson, M. (2001). Knowledge work: ambiguity, image and identity. Human Relations, 54 (7), 863-886.

Alvesson, M. (2010). Self-doubters, strugglers, storytellers, surfers and others: images of selfidentities in organization studies. Human Relations, 63 (2), 193-217.

Alvesson, M. (2011). Interpreting interviews. London: Sage Publications Ltd.

Alvesson, M., \& Empson, L. (2008). The construction of organizational identity: Comparative case studies of consulting firms. Scandinavian Journal of Management, 24 (1), $1-16$.

Alvesson, M., \& Kärreman, D. (2000). Taking the linguistic turn in organizational research: Challenges, responses, consequences. Journal of Applied Behavioural Science, 36 (2), 134156.

Alvesson, M., \& Kärreman, D. (2011). Qualitative research and theory development: Mystery as method. London: Sage Publications Ltd.

Beech, N. (2008). On the nature of dialogic identity work. Organization, 15 (1), 51-74.

Beech, N., McLeod, C., Cochrane, E., \& Greig, G. (2012). Identity work as a response to tensions: A re-narration in opera rehearsals. Scandinavian Journal of Management, (forthcoming).

Belova, O. (2010). Polyphony and the sense of self in flexible organizations. Scandinavian Journal of Management, 26 (1), 67-76.

Bergstrom, O., Hasselbladh, H., \& Kärreman, D. (2009). Organizing disciplinary power in a knowledge organization. Scandinavian Journal of Management, 25 (2): 178-190.

Boje, D. (2001). Narrative methods for organizational and communication research. London: Sage Publications Ltd.

Brante, T. (1988). Sociological approaches to the professions. Acta Sociologica, 31 (2), 119142.

Brown, A. D. (1998). Narrative, politics and legitimacy in an IT implementation. Journal of Management Studies, 35 (1): 35-58. 
Brown, A. D. (2001). Organization studies and identity: towards a research agenda. Human Relations, 54 (1): 113-121.

Brown, D. D. (1997). On narrative and belonging. In M. Joy (Ed.), Paul Ricoeur and narrative: Context and contestations (pp.109-120). Calgary: University of Calgary Press.

Clarke, C.A., Knights, D., \& Jarvis, C. (2012). A labour of love? Academics in business schools. Scandinavian Journal of Management, (forthcoming).

Collinson, D. L. (2003). Identities and insecurities: Selves at work. Organization, 10 (3): $527-547$.

Coupland, C. (2007). Identities and interviews. In A. Pullen, N. Beech \& D. Sims (Eds.), Exploring identity: concepts and methods (pp. 274-287). Basingstoke: Palgrave Macmillan.

Covaleski, M. A., Dirsmith, M. W., Heian, J. B., \& Samuel, S. (1998). The calculated and the avowed: techniques of discipline and struggles over identity in big six public accounting firms. Administrative Science Quarterly, 43 (2), 293-327.

Cunliffe, A. L., Luhman, J. T., \& Boje, D. M. (2004). Narrative temporality: Implications for organizational research. Organization Studies, 25 (2), 261-286.

Czarniawska, B. (1997). A four times told tale: Combining narrative and scientific knowledge in organization studies. Organization, 4 (1), 7-30.

Design Business Association (2011). Design Effectiveness Awards: About the awards. http://www.effectivedesign.org.uk/about.php (Accessed 14th July 2011).

Deuten, J. J., \& Rip, A. (2000). Narrative infrastructure in product creation processes. Organization, 7 (1), 69-93.

Down, S., \& Reveley, J. (2009) Between narration and interaction: Situating first-line supervisor identity work. Human Relations, 62 (3), 379-401.

Dunne, J. (1996). Beyond sovereignty and deconstruction: the storied self. In R. Kearney (Ed.), Paul Ricoeur: The hermeneutics of action (pp.137-158). London: Sage Publications Ltd.

Durand, R., \& Calori, R. (2006). Sameness, otherness? Enriching organizational change theories with philosophical considerations on the same and the other. Academy of Management Review, 31 (1), 93-114.

Eakin, P.J. (2006). Narrative identity and narrative imperialism: A response to Galen Strawson and James Phelan. Narrative, 14 (2), 180-187.

Elsbach, K. D. (2003). Relating physical environment to self-categorizations: Identity threat and affirmation in anon-territorial office space. Administrative Science Quarterly, 48 (4), 622-654. 
Elsbach, K. D., \& Bhattacharya, C. B. (2001). Defining who you are by what you're not: Organizational disidentification and the National Rifle Association. Organization Science, 12 (4), 393-413.

Ezzy, D. (1998). Theorizing narrative identity: Symbolic interactionism and hermeneutics. The Sociological Quarterly, 39 (2), 239-252.

Fine, G. A. (1996). Justifying work: occupational rhetorics as resources in restaurant kitchens. Administrative Science Quarterly, 41 (1), 90-115.

Fleming, J. H., \& Rudman, L. A. (1993). Between a rock and a hard place: Self-concept regulating and communicative properties of distancing behaviors. Journal of Personality and Social Psychology, 64 (1), 44-59.

Gabriel, Y. (2000). Storytelling in organizations: Facts, fictions, and fantasies. Oxford, Oxford University Press.

Gabriel, Y., Gray, D. E., \& Goregaokar, H. (2010). Temporary derailment or the end of the line? Managers coping with unemployment at 50. Organization Studies, 31 (12), 1687-1712.

Glynn, M. A. (2000). When cymbals become symbols: Conflict over organizational identity within a symphony orchestra. Organization Science, 11 (3), 285-298.

Goffman, E. (1959). The Presentation of Self. London: Penguin.

Gotsi, M., Andriopoulos, C., Lewis, M. W., \& Ingram, A. E. (2010). Managing creatives: Paradoxical approaches to identity regulation. Human Relations, 63 (6), 781-805.

Grandy, G. (2008). Managing spoiled identities: Dirty workers' struggles for a favourable sense of self. Qualitative Research in Organizations and Management: An International Journal, 3 (3), 176-198.

Grey, C. (1994). Career as a project of the self and labour process discipline. Sociology, 28 (2), 479-497.

Hackley, C., \& Kover, A. J. (2007). The trouble with creatives: Negotiating creative identity in advertising agencies. International Journal of Advertising, 26(1), 63-78.

Hallier, J. and Summers, J. (2011). Dilemmas and outcomes of professional identity construction among students of human resource management, Human Resource Management Journal, 21 (2), 204-219.

Hamilton, E. (2006). Narratives of enterprise as epic tragedy. Management Decision, 44 (4), 536-550.

Hogg, M. A., \& Terry, D. J. (2000). Social identity and self-categorization processes in organizational contexts. Academy of Management Review, 25 (1), 121-140.

Hytti, U. (2004). New meanings for entrepreneurs: From risk-taking heroes to safe-seeking professionals. Journal of Organizational Change Management, 18 (6), 594-611. 
Ibarra, H., \& Barbulescu, R. (2010). Identity as narrative: prevalence, effectiveness, and consequences of narrative identity work in macro work role transitions. Academy of Management Review, 35 (1), 135-154.

Jabri, M. (2004). Change as shifting identities: A dialogic perspective. Journal of Organizational Change Management, 17 (6), 566-577.

Jabri, M. (2009). Promoting exchange between East and West management cultures: The role of dialogue. Journal of Management \& Organization, 15 (4), 514-525.

Kärreman, D., \& Alvesson, M. (2004). Cages in tandem: Management control, social identity, and identification in a knowledge-intensive firm. Organization, 11 (1), 149-175.

Kelloway, E. K., \& Barling, J. (2000). Knowledge work as organizational behavior. International Journal of Management Reviews, 2 (3): 287-304.

Kinnie, N., \& Swart, J. (2011). Committed to whom? Professional knowledge worker commitment in cross-boundary organisations. Human Resource Management Journal, doi: 10.1111/j.1748-8583.2011.00172.x.

Kreiner, G. E., Hollensbe, E. C., \& Sheep, M. L. (2006a). Where is the 'me' among the 'we'? Identity work and the search for optimal balance. Academy of Management Journal, 49 (5), 1031-1057.

Kreiner, G. E., Hollensbe, E. C., \& Sheep, M. L. (2006b) On the edge of identity: Boundary dynamics at the interface of individual and organizational identities. Human Relations, 59 (10), 1315-1341.

Lei, D., Slocum, J. W., \& Pitts, R. A. (1999). Designing organizations for competitive advantage: The power of unlearning and learning, Organizational Dynamics, 27 (3), 24-38.

Mead, G. H. (1934). Mind, Self and Society. Chicago: University of Chicago Press.

Michlewski, K. (2008). Uncovering design attitude: Inside the culture of designers. Organization Studies, 29 (3), 373-392.

Miles, M. B., \& Huberman, A. M. (1994). Qualitative data analysis: an expanded sourcebook. Thousand Oaks: Sage Publications Inc.

Phelan, J. (2005). Who's here? Thoughts on narrative identity and narrative imperialism. Narrative, 13 (3), 205-10.

Rainwater, M. (1996). Refiguring Ricoeur: Narrative force and communicative ethics. In R. Kearney (Ed.), Paul Ricoeur: The hermeneutics of action (pp.99-110). London: Sage Publications Ltd.

Rasmussen, D. (1996). Rethinking subjectivity: Narrative identity and the self. In In R. Kearney (Ed.), Paul Ricoeur: The hermeneutics of action (pp.159-172). London: Sage Publications Ltd.

Reedy, P. (2009). The manager's tale: Stories of managerial identity. Farnham: Ashgate. 
Rhodes, C., \& Brown, A. D. (2005). Narrative, organizations and research. International Journal of Management Reviews, 7 (3), 167-188.

Ricoeur, P. (1980). Essays on biblical interpretation. (Ed.) L. S. Mudge. Philadelphia: Fortress Press.

Ricoeur, P. (1984). Time and narrative: Volume 1 (K. McLaughlin \& D. Pellauer, Trans.). Chicago: University of Chicago Press.

Ricoeur, P. (1988). Time and narrative: Volume 3 (K. McLaughlin \& D. Pellauer, Trans.). Chicago: University of Chicago Press.

Ricoeur, P. (1991). Narrative identity. Philosophy Today, 35 (1), 73-81.

Ricoeur, P. (1992). Oneself as another (K. Blamey, Trans.). Chicago: University of Chicago Press.

Sims, D. (2003). Between the millstones: A narrative account of the vulnerability of middle managers' storying. Human Relations, 56 (10), 1195-1211.

Slay, H. S., \& Smith, D. A. (2011). Professional identity construction: Using narrative to understand the negotiation of professional and stigmatized cultural identities, Human Relations, 64 (1), 85-107.

Somers, M. R. (1994). The narrative constitution of identity: a relational and network approach. Theory and Society, 23 (5), 605-649.

Sparrowe, R. T. (2005). Authentic leadership and the narrative self. The Leadership Quarterly, 16 (3): 419-439.

Starbuck, W. H. (1992). Learning by knowledge-intensive firms. Journal of Management Studies, 29 (6), 713-740.

Stark, D. (2009). The sense of dissonance: accounts of worth in economic life. Princeton: Princeton Univeristy Press.

Steyaert, C. (2007). Of course that is not the whole (toy) story: Entrepreneurship and the cat's cradle. Journal of Business Venturing, 22 (5), 733-751.

Strangleman, T. (1999). The nostalgia of organizations and the organization of nostalgia: Past and present in the contemporary railway industry. Sociology, 33 (4), 725-746.

Strawson, G. (2004). Against narrativity. Ratio, 17 (4), 428-52.

Sveningsson, S., \& Alvesson, M. (2003). Managing managerial identities: Organizational fragmentation, discourse and identity struggle. Human Relations, 56 (10), 1163-1193.

Swaminathan, A. (2001). Resource partitioning and the evolution of specialist organizations: The role of location and identity in the U.S. wine industry. Academy of Management Journal, 44 (6), 1169-1185. 
Swart, J. (2007). HRM and knowledge workers. In P. Boxall, J. Purcell, \& P. M. Wright (Eds.), The Oxford handbook of human resource management (pp. 450-468). Oxford: Oxford University Press.

Swart, J., \& Kinnie, N. (2003a). Sharing knowledge in knowledge-intensive firms. Human Resource Management Journal, 13(2), 60-75.

Swart, J., \& Kinnie, N. (2003b). Knowledge-intensive firms: the influence of the client of HR systems. Human Resource Management Journal, 13 (3), 37-55.

Tsoukas, H., \& Hatch, M. J. (2001). Complex thinking, complex practice: The case for a narrative approach to organizational complexity. Human Relations, 54 (8), 979-1013.

Watson, T. J. (2008). Managing identity: Identity work, personal predicaments and structural circumstances. Organization, 15 (1), 121-143.

Watson, T. J. (2009). Narrative, life story and manager identity: a case study in autobiographical identity work. Human Relations, 62 (3), 425-452.

Ybema, S., Keenoy, T., Oswick, C., Beverungen, A., Ellis, N., \& Sabelis, I. (2009). Articulating identities. Human Relations, 62 (3), 299-322.

Ybema, S., Vroemisse, M., \& Marrewijk, A.H. van (2012). Scandinavian Journal of 